
больных фибрилляцией предсердий в сочетании с артериальной гипертонией и экстракардиальной патологией

Яхонтов Д.А. ${ }^{1}$, Хидирова Л.Д. ${ }^{1}$, Зенин С.А. ${ }^{2}$

${ }^{1}$ ФББОУ ВО «Новосибирский государственный медицинский университет» Минздрава России

${ }^{2}$ Новосибирский областной клинический кардиологический диспансер

\title{
Assessment of some clinical pathogenetic interactions in patients with atrial fibrillation in combination with the arterial hypertension and extracardiac pathology
}

\author{
Yakhontov D.A. ${ }^{1}$, Khidirova L.D. ${ }^{1}$, Zenin S.A. ${ }^{2}$ \\ ${ }^{1}$ Novosibirsk State Medical University \\ ${ }^{2}$ Novosibirsk Regional Clinical Cardiologic Dispensary
}

\begin{abstract}
АННОТАЦИЯ
В проспективном когортном исследовании участвовали 173 мужчины 45-65 лет с артериальной гипертонией (АГ) и фибрилляцией предсердий (ФП). Больные были разделены на 3 группы: 1-я группа - 53 пациента с абдоминальным ожирением (АО) и сахарным диабетом (СД) типа 2; 2-я группа - 64 больных с АО без СД; 3-я группа, группа сравнения - 56 больных АГ и ФП без сопутствующей патологии. Исследуемые группы различались по возрасту: средний возраст больных 1-й и 2-й группы был значимо выше, чем у больных группы сравнения. При сравнении биохимических показателей оказалось, что у больных 1-й и 2-й группы уровень калия, мочевины и креатинина крови был достоверно выше по отношению к больным группы сравнения. Маркер фиброза галектин-3 у больных 1-й группы был выше, чем у больных группы сравнения. У пациентов 1-й и 2-й групп отмечалось достоверное уменьшение индекса массы миокарда левого желудочка (ИММЛЖ) по отношению к группе сравнения. Снижение ИММЛЖ при сопутствующей коморбидной патологии может быть связано с метаболическими процессами, которые могут замедлять компенсаторную мышечную гипертрофию миокарда.

Таким образом, больным с фибрилляцией предсердий на фоне артериальной гипертонии, абдоминального ожирения и сахарного диабета необходима ранняя диагностика и коррекция как АГ, так и экстракардиальных коморбидных заболеваний с целью профилактики раннего и быстро прогрессирующего поражения миокарда.
\end{abstract}

Ключевъе слова: фибрилляция предсердий, артериальная гипертония, нарушение ритма сердца, сахарный диабет, абдоминальное ожирение.

\begin{abstract}
A prospective cohort study included 173 men 45-65 years with arterial hypertension (AH) and atrial fibrillation (AF). The $1^{\text {st }}$ group consisted 53 patients with abdominal obesity (AO) and with diabetes mellitus of type 2 ; the $2^{\text {nd }}$ group consisted 64 patients with $\mathrm{AO}$ without diabetes mellitus; the $3^{\text {rd }}$ group was the comparison one it included 56 patients with $\mathrm{AH}$ and $\mathrm{AF}$ without accompanied pathology. The studied groups differed on age: average of patients of the $1^{\text {st }}$ and $2^{\text {nd }}$ group was reliably senior, than in patients of the comparison group. During the comparison of biochemical parameters it was found that patients of the $1^{\text {st }}$ and $2^{\text {nd }}$ group had a significant increase in potassium, creatinine, urea compared of the comparison group higher. The fibrosis marker galectin- 3 was higher in patients of the $1^{\text {st }}$ group then in patients of the control group. In patients of the $1^{\text {st }}$ and $2^{\text {nd }}$ group there was a significant decrease of the index of mass a myocardium of the left ventricular (IMMLV) compared to patients of the comparison group. The decrease of the IMMLV with concomitant comorbid pathology may be associated with metabolic processes that can slow compensatory muscular hypertrophy of the myocardium.
\end{abstract}

Поступила 20.09.2018

Принята 12.11.2018

*Автор, ответственный за переписку

Хидирова Людмила Даудовна: ФГБОУ ВО «Новосибирский государственный медицинский университет» Минздрава России. 630091, г. Новоси-

бирск, Красный просп., 52.

E-mail: h_ludmila73@mail.ru
Received 20.09.2018

Accepted 12.11.2018

*Corresponding author

Khidirova Ludmila Daudovna: Novosibirsk State Medical University, 52, Krasny Prospect, Novosibirsk, 630091, Russia.

E-mail: h_ludmila73@mail.ru 
Thus, patients with atrial fibrillation on the background of arterial hypertension, abdominal obesity and diabetes mellitus needed early diagnostics and correction of both $\mathrm{AH}$ and extracardial comorbid diseases in order to prevent early and rapidly progressive myocardial lesions.

\section{Keywords: atrial fibrillation, arterial hypertension, cardiac arrhythmia, diabetes mellitus, abdominal obesity.}

\section{$\mathbb{B B E}$ ВЕНИЕ}

Фибрилляция предсердий (ФП) является одним из наиболее часто встречающихся нарушений ритма и составляет примерно 30 \% среди всех аритмий. Однако следует признать, что ФП до сих пор остается серьезной и во многом нерешенной проблемой для практических врачей и исследователей. В качестве патогенетических механизмов ФП рассматриваются острые или хронические гемодинамические, метаболические и электрофизиологические нарушения сердечно-сосудистой системы $[1,2]$. Все эти факторы способны привести к структурному ремоделированию предсердий, вследствие чего развивается и прогрессирует ФП. Помимо этого, в соответствии с современными концепциями, одну из ведущих ролей в патогенезе ФП играет иммуновоспалительная активация [3]. Динамика воспалительного процесса независимо от его причин всегда достаточно стандартна, т. е. воспаление, по существу, является «монопатогенетическим» процессом [4]. Аритмии сердца являются серьезным, часто фатальным проявлением различных состояний и вызывают значительное напряжение нейрогуморальных механизмов, ответственных за поддержание гомеостаза в организме. В свою очередь, изменение функциональной активности нервной и эндокринной систем вовлекает в процесс адаптации систему иммунитета, которая по современным представлениям является третьей регулирующей системой, способной активно влиять на нейрогуморальную сферу [5].

Фибрилляция предсердий является гетерогенным заболеванием, и на сегодняшний день доказана ее связь с другими соматическими заболеваниями, в том числе и некоронарогенной природы (артериальная гипертония (АГ), приобретенные пороки сердца, тромбоэмболии, кардиомиопатии, сахарный диабет, абдоминальное ожирение, хроническая обструктивная болезнь легких и т. д.) [6]. В недавних исследованиях была показана роль новых факторов риска возникновения первичной ФП, таких как воспаление, фиброз, оксидативный стресс [7].

Возрастает значимость биомаркеров, способных отражать патофизиологические процессы, такие как воспаление с исходом в фиброз и ремо-

\section{INTRODUCTION}

The atrial fibrillation (AF) is one of the most often found rhythm disorder and makes about $30 \%$ among all case of arrhythmia. However it is necessary to recognize that AF serious and in many respects an unsolved problem for practical doctors and researchers. An acute or chronic hemodynamic, metabolic and electrophysiological disorder of cardiovascular system are considered as the pathogenetic mechanisms of AF $[1,2]$. All these factors are able to lead to structural remodeling of atria, therefore $\mathrm{AF}$ develops and progresses. In addition, the immunoinflammatory activation is at the forefront of pathogenesis of AF according to modern concepts [3]. Dynamics of inflammatory process is always standard independently of its reasons, that is the inflammationis -"monopathogenetic" process [4]. Cardiac arrhythmias are serious, often fatal manifestation of various states and cause the considerable tension of the neurohumoral mechanisms responsible for maintenance of a homeostasis in an organism. In its turn, the change of functional activity of nervous and endocrine systems involves in adaptation process the system of immunity which on modern representations is the third regulating system capable to influence actively the neurohumoral sphere [5].

Atrial fibrillation is a heterogeneous disease. Nowadays it is proved its link with other somatic diseases including the diseases of the non-coronarogenic nature (the arterial hypertension (AF)), the acquired valvular disease, a thrombembolism, a cardiomyopathy, diabetes mellitus, abdominal obesity, a chronic obstructive pulmonary disease, etc. [6]. In recent researches the role of new risk factors of appearance of primary AF, such as inflammation, fibrosis, an oxidative stress have been shown [7].

The importance of the biomarkers capable to reflect pathophysiological processes, such as inflammation from the outcome in fibrosis and remodeling of a myocardium increases [8]. Galektin-3 is such biomarkers, which role at atrial fibrillation is actively investigated now. It has been shown that galektin-3 - an excellent target for treatment of fibrosis. 
делирование миокарда [8]. К таким биомаркерам относится, в частности, галектин-3, роль которого при фибрилляции предсердий активно изучается в настоящее время. Было показано, что галектин-3 - отличная мишень для лечения фиброза. В эксперименте с искусственно вызванным фиброзом печени включение в пищевой рацион животных специфического ингибитора галектина-3 позволило не только приостановить развитие фиброза миокарда, но и вызвать его регресс $[9,10]$.

В наблюдательном исследовании обнаружено, что сахарный диабет (СД) и/или АГ ассоциированы с развитием ФП [8], при этом ассоциация СД и АГ с ФП была значительной при учете сердечно-сосудистых факторов риска [11]. Полученные данные позволили предположить, что гипергликемия увеличивает риск возникновения новых случаев ФП у пациентов с СД и АГ [12]. Во Фрамингемском исследовании (2014) было показано, что сахарный диабет способствует появлению новых случаев ФП в большой когорте мужчин и женщин в возрасте старше 38 лет (относительный риск для мужчин -1.4 , для женщин 1.6) $[13,14]$.

Абдоминальное ожирение (АО) является частым спутником и лидирующим фактором риска развития АГ и способствует структурнофункциональной перестройке миокарда, описанной как феномен липотоксичности. Последняя включает в себя аккумуляцию триглицеридов в миокарде, что приводит к миокардиальному стеатозу и формированию последующей дилатации полостей сердца [14].

Актуальность нашего исследования продиктована тем, что в результате АГ в сочетании с метаболическими нарушениями (СД, АО) возникает поражение миокарда, связанное с недостаточно контролируемым повышенным АД и дистрофией предсердий вместе с гипертрофией желудочков сердца и нарушением ритма сердца уже в самом начале сердечно-сосудистого континуума. В связи с этим необходима ранняя диагностика и коррекция как АГ, так и коморбидных состояний для предотвращения развития ФП [15].

\section{ЦЕЛЬ ИССЛЕДОВАНИЯ}

Изучить клинико-патогенетические взаимосвязи у больных с фибрилляцией предсердий и артериальной гипертонией в сочетании с экстракардиальными коморбидными заболеваниями.

\section{МАТЕРИАЛЫ И МЕТОДЫ}

В проспективном когортном исследовании приняли участие 173 мужчины 45-65 лет с артериальной гипертонией и фибрилляцией пред-
In an experiment with artificially caused liver fibrosis inclusion in a diet of animals of specific inhibitor galektin-3 has allowed not only to suspend the development of fibrosis of a myocardium, but also to cause its regress $[9,10]$.

In an research it is revealed that the diabetes mellitus (DM) and/or AH are associated with development of $\mathrm{AF}$ [8], at the same time the $\mathrm{DM}$ and $\mathrm{AH}$ association with $\mathrm{AF}$ was considerable during the management of cardiovascular risk factors [11]. The obtained data have allowed to assume that the hyperglycemia increases risk of the appearance of new cases of $\mathrm{AF}$ at patients with $\mathrm{DM}$ and $\mathrm{AH}$ [12]. In the Framingem's research (2014) it has been shown that diabetes mellitus promotes the appearance of new cases of AF in a big cohort of men and women at the age of 38 (relative risk for men -1.4 , for women 1.6) $[13,14]$.

The abdominal obesity (AO) is frequently the leading risk factor of development of $\mathrm{AH}$ and promotes the structural-functional reorganization of a myocardium described as a lipotoxicity phenomenon. The last includes accumulation of triglycerides in a myocardium that leads to a myocardial steatosis and formation of the subsequent dilatation of heart cavities [14].

The topicality of our research is dictated by the fact that as a result of $\mathrm{AH}$ in combination with metabolic violations (DM, AO) there is myocardial damage connected with insufficiently controllable increased blood pressure and dystrophy of atria together with a hypertrophy of ventricles of heart and cardiac rhythm disorder already at the very beginning of a cardiovascular continuum. In this case it is necessary early diagnostics and correction both AH and comorbid conditions for prevention of development of AF [15].

\section{AIM OF THE RESEARCH}

To study clinical pathogenetic interrelations at patients with atrial fibrillation and an arterial hypertension in combination with extracardiac comorbid diseases.

\section{MATERIALS AND METHODS}

173 men at the age of 45-65 with an arterial hypertension and atrial fibrillation have participated in prospective cohort study. The $1^{\text {st }}$ group included 53 patients with abdominal obesity with diabetes mellitus of type 2 among them (Clinical recommendations "Algorithms of specialized medical care by patients with diabetes mellitus", Moscow, 2017). 
сердий, из них 53 больных абдоминальным ожирением с сахарным диабетом типа 2 (Клинические рекомендации «Алгоритмы специализированной медицинской помощи больным сахарным диабетом», М., 2017) - 1-я группа; 64 больных абдоминальным ожирением без сахарного диабета (Клинические рекомендации «Диагностика, лечение, профилактика ожирения и ассоциированных с ним заболеваний», Санкт-Петербург, 2017) - 2-я группа и 56 больных АГ и ФП (группа сравнения) без сопутствующих заболеваний и с отсутствием абдоминального ожирения (индекс массы тела (ИМТ) 20-25). В исследование не включались больные с документированной ишемической болезнью сердца.

Больным проводились стандартное общеклиническое обследование; биохимический анализ крови; УЗИ сердца, а также определение концентрации NT-proBNP с использованием набора реагентов «NTproBNP - ИФA - Бест» (АО «ВекторБест», Россия) и галектина-3 методом ИФА (Bender MedSystems GmbH, Австрия).

Эмпирические распределения данных испытывались на согласие с законом нормального распределения по критериям Шапиро - Уилка, Андерсона - Дарлинга, Крамера - фон Мизеса, Лиллиефорса и Шапиро - Франсиа. Для статистической проверки гипотез о равенстве числовых характеристик выборочных распределений в сравниваемых группах использовался непарный $U$-критерий Манна - Уитни, производился расчет смещения распределений с построением 95\% доверительного интервала для смещения. Для сравнения бинарных и категориальных показателей применялся точный двусторонний критерий Фишера. Проверка статистических гипотез проводилась при критическом уровне значимости $p=0.05$, т. е. различие считалось статистически значимым, если $p<0.05$.

\section{РЕЗУЛЬТАТЫ И ОБСУЖКДЕНИЕ}

Исследуемые группы различались по возрасту: так, средний возраст больных 1-й группы $-59 \pm 7.2$ года и 2-й группы $60 \pm 4.1$ года был достоверно выше, чем в группе сравнения $57 \pm 2.1$ года $(52 ; 63) ;(p<0.001)$. При сравнении биохимических показателей оказалось, что у пациентов 1-й и 2-й группы были достоверно выше значения мочевины, креатинина и калия крови, чем в группе сравнения. В то же время в группе сравнения данные показатели имели наиболее низкие значения (табл. 1). При оценке липидного спектра достоверные различия были получены только в отношении холестерина (XC) липо-
The $2^{\text {nd }}$ group included 64 patients with abdominal obesity without diabetes mellitus (Clinical recommendations "Diagnostics, treatment, prevention of obesity and the diseases associated with it", St. Petersburg, 2017). And there were 56 patients with $\mathrm{AH}$ and AF ( comparison group) without associated diseases and with absence of abdominal obesity (index of body weight 20-25). The research didn't include patients with documentary coronary heart disease.

A standard general examination was carried out to the patients. There were biochemical blood test, ultrasonography of heart and also estimation of concentration of NT-proBNP with use of set of reagents "NTproBNP-IFA-Best" ("Vektor-Best", Russia) and galektin-3 by IFA method (Bender MedSystems GmbH, Austria).

Empirical distributions of data were tested on consent with the law of normal distribution by Shapiro - Wilk test, Anderson - Darling test, Cramer - von Mises criterion, Lilliefors test and Shapiro - Francia test. The unpaired $U$-criterion of Mann - Whitney was used for statistical check of hypotheses of equality of numerical characteristics of selective distributions in the compared groups. It was made a calculation of shift of distributions with creation of $95 \%$ of a confidential interval for shift. The exact bilateral criterion of Fischer was applied to comparison of binary and categorial indicators. A testing of statistical hypotheses was carried out at critical significance value $p=0.05$, that is the difference was considered as statistically significant if $p<0.05$.

\section{RESULTS AND DISCUSSION}

The age of the studied groups was different: average age of patients in the $1^{\text {st }}$ group ( $59 \pm 7.2$ years) and the in the $2^{\text {nd }}$ group ( $60 \pm 4.1$ years) was reliably over, than in comparison group $(57 \pm 2.1$ years $(52$; 63)) ( $p<0.001)$. When comparing biochemical indicators it was estimated that at patients of the $1^{\text {st }}$ and $2^{\text {nd }}$ group the values of urea, creatinine and potassium of blood were reliably over, than in comparison group. At the same time in comparison group these indicators had the lowest values (Table 1). At assessment of a lipidic range reliable differences have been received only concerning cholesterol (Ch) of lipoproteins of high density which values were the greatest in comparison group (see Table 1).

It was studied the content of brain natriuretic peptide and galektin-3 as the markers reflecting processes of remodeling and fibrosis of a myocardium at patients with atrial fibrillation in combination 
Таблица 1. Биохимические показатели больных АГ с ФП и экстракардиальной патологией

Table 1. Biochemical indicators of the patients, who have AH with AF and extracardiac pathology

\begin{tabular}{|c|c|c|c|c|}
\hline Показатель / Indicator & $\begin{array}{l}\text { Группа } 1 / \text { Group } 1 \\
(n=53)\end{array}$ & $\begin{array}{l}\text { Группа } 2 / \text { Group } 2 \\
(n=64)\end{array}$ & $\begin{array}{l}\text { Группа сравнения / } \\
\text { Comparison group } \\
(n=56)\end{array}$ & $\begin{array}{l}p \\
\text { группа } 1 \text { / группа } 2 \\
\text { group } 1 \text { / group } 2\end{array}$ \\
\hline $\begin{array}{l}\text { Общий XC, ммоль/л } \\
\text { Total Ch, mmol/l }\end{array}$ & $5.02(4.16 ; 6.04)$ & $5.0(4.37 ; 5.6)$ & $5.02(4.16 ; 6.04)$ & $0.269 / 0.485$ \\
\hline $\begin{array}{l}\text { ХС липопротеидов низкой } \\
\text { плотности, ммоль/л } \\
\text { Ch of low density lipoproteins, } \\
\text { mmol/l }\end{array}$ & $2.42(2.13 ; 3.02)$ & $2.57(2.03 ; 3.18)$ & $2.42(2.13 ; 3.02)$ & $0.364 / 0.656$ \\
\hline $\begin{array}{l}\text { ХС липопротеидов высокой } \\
\text { плотности, ммоль/л } \\
\text { Ch of high density } \\
\text { lipoproteins, mmol/l }\end{array}$ & $1.4(1.22 ; 1.72)$ & $1.4(1.79 ; 3.44)$ & $2.31(1.04 ; 1.85)$ & $0.732 / 0.001^{*}$ \\
\hline $\begin{array}{l}\text { Триглицериды, ммоль/л } \\
\text { Triglycerids, mmol/l }\end{array}$ & $2.4(1.04 ; 2.85)$ & $2.51(1.24 ; 2.86)$ & $1.4(1.22 ; 1.72)$ & $0.891 / 0.292$ \\
\hline $\begin{array}{l}\text { Креатинин, мкмоль/л } \\
\text { Creatinine, mcmol/l }\end{array}$ & $\begin{array}{l}112.55 \\
(109.16 ; 124.84)\end{array}$ & $\begin{array}{l}117.7 \\
(99.02 ; 148.29)\end{array}$ & $\begin{array}{l}101.7 \\
(94.92 ; 117.29)\end{array}$ & $0.004 * / 0.035^{*}$ \\
\hline $\begin{array}{l}\text { Мочевина, ммоль/л } \\
\text { Urea, mmol/l }\end{array}$ & $\begin{array}{l}6.21 \\
(5 \cdot 31 ; 7.63)\end{array}$ & $\begin{array}{l}6.21 \\
(5 \cdot 31 ; 7.63)\end{array}$ & $\begin{array}{l}5.4 \\
(4.6 ; 6.76)\end{array}$ & $0.009^{*} / 0.004^{*}$ \\
\hline $\begin{array}{l}\text { Калий, ммоль/л } \\
\text { Potassium, mmol/l }\end{array}$ & $\begin{array}{l}4.3 \\
(4.1 ; 4.43)\end{array}$ & $\begin{array}{l}4.9 \\
(4.07 ; 4.9)\end{array}$ & $\begin{array}{l}4.0 \\
(3.8 ; 4.2)\end{array}$ & $0.001^{*} / 0.003^{*}$ \\
\hline
\end{tabular}

* Различия достоверны (при $p<0.05$ ) по $U$-критерию Манна - Уитни.

Differences are reliable (at $p<0.05$ ) by Mann's - Whitney $U$-criterion.

протеидов высокой плотности, значения которого были наибольшие в группе сравнения (см. табл. 1).

Также изучалось содержание мозгового натрийуретического пептида и галектина-3, как маркеров, отражающих процессы ремоделирования и фиброза миокарда у больных фибрилляцией предсердий в сочетании с артериальной гипертонией. Средний уровень NT-proBNP в 1-й группе составил 123.8 пг/мл $(42.92 ; 157.02)(p<0.001)$; во 2-й группе - 98.27 пг/мл (51.11; 156.85) ( $p=0.387)$, достоверно превышая значение этого показателя в группе сравнения - 67.99 пг/мл (33.5; 115.2) ( $p<$ o.001). Несмотря на то, что все средние значения укладываются в рекомендуемый референсный интервал, у больных в 1-й группе все же обнаружены наибольшие значения данного показателя, а у 19.1 \% из них он превышал референсные значения (150 пг/мл).

Уровень галектина-3 в сыворотке крови у больных АГ с ФП в сочетании с абдоминальным ожирением был выше, чем у больных группы сравнения, независимо от наличия либо отсутствия СД. Хотя следует отметить, что у пациентов с сочетанием АО и СД (1-я группа) данный показатель был достоверно выше, чем у лиц с АО (2-я группа) и неизмененным углеводным обменом. Так, в 1-й группе содержание галектина-3 соста- with an arterial hypertension. The average level of NT-proBNP in the $1^{\text {st }}$ group was $123.8 \mathrm{pg} / \mathrm{ml}(42.92$; 157.02 ) ( $p<0.001)$; in the $2^{\text {nd }}$ group it was 98.27 $\mathrm{pg} / \mathrm{ml}(51.11 ; 156.85)(p=0.387)$, reliably it was exceeded value of this indicator in group of comparison $-67.99 \mathrm{pg} / \mathrm{ml}(33.5 ; 115.2)(p<0.001)$. In spite of the fact that all average values are within the recommended reference interval the greatest values of this indicator are found in patients in the $1^{\text {st }}$ group and at $19.1 \%$ of them it exceeded reference values (150 pg/ml).

The level of galektin-3 in blood serum at patients, who have $\mathrm{AH}$ with $\mathrm{AF}$ in combination with abdominal obesity was higher, than at patients of comparison group, irrespective of existence or lack of DM. Though it should be noted, that patients with a combination of the AO and DM (the $1^{\text {st }}$ group) had this indicator reliably over, than at persons with the AO (the $2^{\text {nd }}$ group) and not changed carbohydrate metabolism. So, the $1^{\text {st }}$ group contained $29.44 \mathrm{ng} / \mathrm{ml}$ (12.70; 97.73) of galektin-3 and the $2^{\text {nd }}$ group it was $17.8 \mathrm{ng} / \mathrm{ml}(11.32 ; 51)$ ( $p=0.005)$, in comparison group o it was $13.23 \mathrm{ng} / \mathrm{ml}(4.97 ; 40.99)$ ( $p=0.001$ and $p=0.009$ respectively) (Fig. 1)

The results of the correlation analysis showed positive connections between level of galektin-3 and existence of $\mathrm{AO}$ in group of patients with existence 

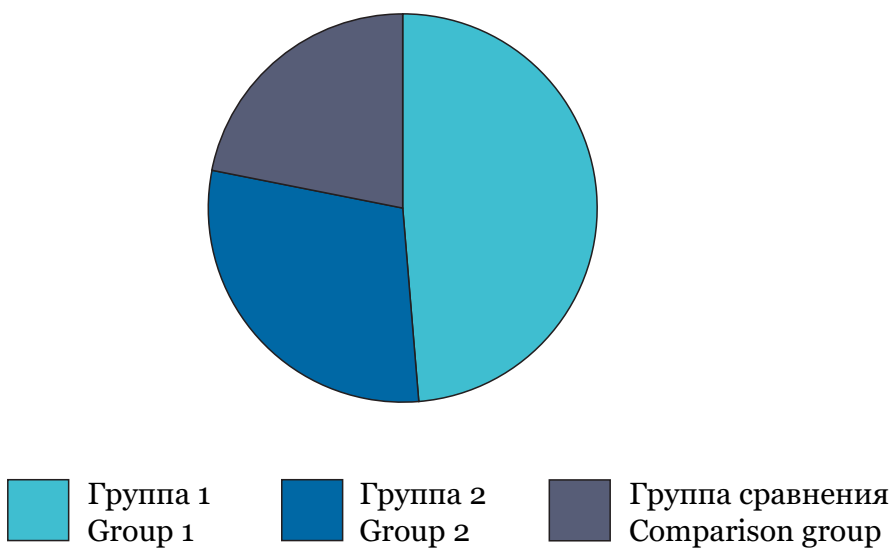

Рис. 1. Оценка уровня галектина-3 в клинических группах Fig. 1. Assessment of the level of galektin-3 in clinical groups

вило 29.44 нг/мл (12.70; 97.73), во 2-й группе 17.8 нг/мл $(11.32 ; 51)$ ( $p=0.005)$, в группе сравнения -13.23 нг/мл $(4.97 ; 40.99)$ ( $p=0.001$ и $p=0.009$ соответственно) (рис. 1$)$.

По результатам корреляционного анализа выявлены достоверные положительные связи между уровнем галектина-3 и наличием абдоминального ожирения в группе больных с наличием и отсутствием СД $(r=0.40 ; r=0.57 ; r=0.51$ соответственно) ( $p<$ o.o01). Полученные данные, таким образом, подтверждают возможную роль галектина-3 как биологического маркера фиброза и ремоделирования миокарда у больных ФП с наличием АГ и ожирения, как при сахарном диабете, так и при его отсутствии, хотя и в меньшей степени выраженности.

Вместе с оценкой биохимических показателей ремоделирования миокарда проводилась ин- and lack of DM ( $r=0.40 ; r=0.57 ; r=0.51$ respectively) ( $p<0.001)$. Thus, the obtained data confirm a possible role of galektin-3 as biological marker of fibrosis and remodeling of a myocardium at patients with $\mathrm{AH}$, existence of $\mathrm{AH}$ and obesity, both at DM, and at its absence in a less degree of expressiveness.

It was carried out instrumental assessment of remodeling of the left ventricle together with assessment of biochemical indicators of remodeling of a myocardium. It was estimated that the index of mass of a myocardium of the left ventricle in comparison group was reliably over $\left(143 \mathrm{~g} / \mathrm{m}^{2}\right.$ $(125 ; 157)$ ), than at the patients of the $1^{\text {st }}$ group $\left(118 \mathrm{~g} / \mathrm{m}^{2}(106.5 ; 131.0)\right)(p<0.001)$ and the $2^{\text {nd }}$ group (121 g/m² $(107 ; 132))(p<0.001)$ (Fig. 2). The sizes of the left atrium in all studied groups were comparable. The final and diastolic size of

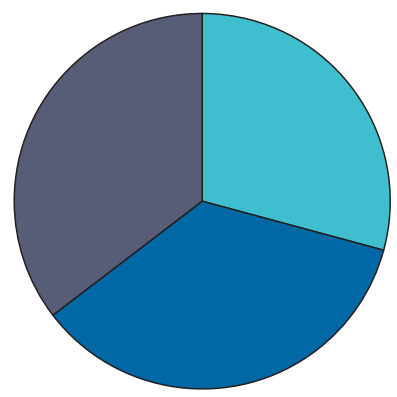

\begin{tabular}{lll|l} 
Группа 1 & $\begin{array}{l}\text { Группа 2 } \\
\text { Group 2 }\end{array}$ & $\begin{array}{l}\text { Группа сравнения } \\
\text { Comparison group }\end{array}$
\end{tabular}

Рис. 2. Оценка индекса массы миокарда левого желудочка в клинических группах

Fig. 2. Assessment of the index of mass of a myocardium of the left ventricle in clinical groups 
струментальная оценка ремоделирования левого желудочка. Оказалось, что индекс массы миокарда левого желудочка (ИММЛЖ) в группе сравнения был достоверно выше - 143 г/ $\mathrm{M}^{2}$ (125; 157), чем у больных 1-й группы - 118 г/ м $^{2}$ (106.5; 131.0) ( $p$ < 0.001) и 2-й группы - 121 г/м² $(107 ; 132)$ ( $p$ < 0.001) (рис. 2). Размеры левого предсердия во всех исследуемых группах были сопоставимы. Конечно-диастолический размер левого желудочка в 1-й группе был достоверно выше - 5.6 см $(4.80 ; 6.15)$, чем в группе сравнения -5.2 см (4.6; 6.0) $(p=0.042)$.

Как показало проведенное исследование, у больных АГ и ФП в сочетании с СД и АО достоверно увеличен уровень калия, мочевины и креатинина крови по отношению к группе сравнения. Маркер фиброза галектин-3 у больных АГ и ФП в сочетании с АО выше при сахарном диабете, чем у больных без наличия экстакардиальной патологии. У больных АГ и ФП в сочетании с СД и АО отмечалось достоверное уменьшение ИММЛЖ по отношению к группе сравнения

\section{ЗАКЛЮЧЕНИЕ}

Наличие коморбидной патологии экстракардиального генеза влияет на выраженность биохимических, гемодинамических и функциональных сдвигов у больных с ФП и АГ. Диагностическая ценность галектина-3 может быть важна в изучении стратификации риска с целью назначения адекватной терапии, мониторировании ответа на назначенную терапию, а также при прогнозировании коротко- и долгосрочной заболеваемости и смертности. Снижение ИММЛЖ при сопутствующей коморбидной патологии может быть связано с метаболическими процессами, которые могут замедлять компенсаторную мышечную гипертрофию миокарда.

У больных с фибрилляцией предсердий на фоне артериальной гипертонии, абдоминального ожирения и сахарного диабета необходима ранняя диагностика и коррекция как АГ, так и экстракардиальных коморбидных заболеваний с целью профилактики раннего и быстро прогрессирующего поражения миокарда.

\section{СПИСОК ЛИТЕРАТУРЫ}

1. Яхонтов Д.А., Зенин С.А., Хидирова Л.Д., Киреева О.В. Характер течения фибрилляции предсердий и артериальной гипертонии в сочетании с некоронарогенными заболеваниями // Journal of Siberian Medical Sciences. 2018. № 1. C. 4-10.

2. Гребенкина И.А., Попова А.А., Маянская С.Д. и др. Состояние стенки каротидной артерии у молодых the left ventricle in the $1^{\text {st }}$ group was reliably over ( $5.6 \mathrm{~cm}(4.80 ; 6.15))$, than in comparison group $(5.2 \mathrm{~cm}(4.6 ; 6.0))(p=0.042)$.

The conducted research has shown, that at the patient with $\mathrm{AH}$ and $\mathrm{AF}$ in combination with $\mathrm{DM}$ and the AO have the increased level of potassium, urea and creatinine of blood in comparison with group of comparison. The fibrosis marker galektin-3 at patients with the $\mathrm{AH}$ and $\mathrm{AF}$ in combination with $\mathrm{AO}$ is higher at DM, than at patients without existence of exstacardial pathology. It was noted reliable reduction of index of mass of a myocardium of the left ventricle at patients with the $\mathrm{AH}$ and $\mathrm{AF}$ in combination with $\mathrm{DM}$ and the $\mathrm{AO}$ in comparison with comparison group.

\section{CONCLUSION}

Existence of comorbid pathology of extracardiac genesis influences expressiveness of biochemical, hemodynamic and functional shifts at patients with AF and AH. Diagnostic consideration of galektin-3 can be important in studying of stratification of risk to purpose of adequate therapy, monitoring of the response to the administered therapy and also when forecasting is short-term and long-term incidence and mortality. Decrease of the index of mass of a myocardium of the left ventricle at the accompanying comorbid pathology can be connected with metabolic processes which can slow down a compensatory muscular hypertrophy of a myocardium.

At patients with atrial fibrillation against the backdrop of an arterial hypertension, abdominal obesity and diabetes mellitus it is necessary an early diagnostics and correction both $\mathrm{AH}$ and exstacardial comorbid diseases for prevention of the early and quickly progressing myocardial damage.

Conflict of interest. The authors declare no conflict of interest.

Конфликт интересов. Авторы заявляют об отсутствии конфликта интересов.

\section{REFERENCES}

1. Yakhontov D.A., Zenin S.A., Khidirova L.D., Kireeva O.V. (2018). Atrial fibrillation and arterial hypertension associated with non-coronarogenic origin diseases. J. Sib. Med. Sci., 1, 4-10.

2. Grebenkina I.A., Popova A.A., Mayanskaya S.D. et al. (2018). Condition of a wall of a carotid artery in young faces with the anamnesis burdened 
лиц с отягощенным по артериальной гипертензии анамнезом // Journal of Siberian Medical Sciences. 2018. № 4 . C. 42-53.

3. Драпкина О.М., Костюкевич М.В. Артериальная гипертензия: от фибрилляции предсердий и инсульта до метаболического синдрома // Справочник поликлинического врача. 2010. № 8. С. 37-39.

4. Драпкина O.М., Емельянов А.В. Фиброз и фибрилляция предсердий - механизмы и лечение // Артериальная гипертензия. 2013. Т. 19, № 6. С. 487-494.

5. Оганов Р.Г. Профилактика сердечно-сосудистых заболеваний: возможности практического здравоохранения //Кардиоваскулярная терапия и профилактика. 2002. № 1. С. 15-16.

6. Ahmad T., Fiuzat M., Neely B. et al. Biomarkers of myocardial stress and fibrosis as predictors of mode of death in patients with chronic heart failure // JACC Heart Fai. 2014. Vol. 2 (3). P. 260-268. doi: 10.1016/j. jchf.2013.12.004

7. Ho J.E., Yin X., Levy D. et al. Galectin 3 and incident atrial fibrillation in the community // Am. Heart J. 2014. Vol. 167 (5). P. 729-734.

8. Belluzzi F., Sernesi L., Preti P. et al. Prevention of recurrence lone atrial fibrillation by the angiotensin-II converting enzyme inhibitor ramipril in normotensive patients // JACC. 2009. Vol. 53. P. 24-29. doi: 10.1016/j. jacc.2008.08.071.

9. Gurses K.M., Yalcin M.U., Kocyigit D. et al. Effects of persistent atrial fibrillation on serum galectin-3 levels // Am. J. Cardiol. 2015. Vol. 115 (5). P. 647-651.

10. Ионин В.А., Листопад О.В., Нифонтов С.Е. и др. Галектин 3 у пациентов с метаболическим синдромом и фибрилляцией предсердий // Артериальная гипертензия. 2014. Т. 20, № 5. С. 462-469.

11. Boss Ch.J., Lip G.Y.H. Targeting the renin-angiotensinaldosterone system in atrial fibrillation: from pathology to clinical trials // J. Hum. Hypertens. 2005. Vol. 19. P. $855-859$.

12. Cheruku K.K., Ghani A., Ahmad F. et al. Efficacy of nonsteroidal anti-inflammatory medications for prevention of atrial fibrillation following coronary artery bypass graft surgery // Prev. Cardiol. 2004. Vol. 7 (1). P. 13-18.

13. Sideris A.N., Letsas K. Inflammation and atrial fibrillation // Hospital Chronicles. 2006. Suppl. P. 128-134.

14. Weber M., Hamm C. Role of B-type natriuretic peptide (BNP) and NT-proBNP in clinical routine // Heart. 2006. Vol. 92 (6). P. 843-849. doi: 10.1136/ hrt.2005.071233.

15. Шляхто Е.В., Недогода С.В., Конради А.О. и др. Концепция новых национальных клинических рекомендаций по ожирению // Рос. кардиол. журн. 2016. T. 21, № 4. C. 7-13. doi.org/10.15829/1560-4071-20164-7-13.

\section{СВЕДЕНИЯ ОБ АВТОРАХ}

Яхонтов Давыд Александрович - д-р мед. наук, профессор кафедры фармакологии, клинической фармакологии и доказательной медицины ФГБОУ ВО «Новосибирский государственный медицинский университет» Минздрава России.

Хидирова Людмила Даудовна - канд. мед. наук, доцент кафедры фармакологии, клинической фар- on arterial hypertension. J. Sib. Med. Sci., 4, 4253 .

3. Drapkina O.M., Kostyukevich M.V. (2010). Arterial hypertension: from atrial fibrillation and a stroke to a metabolic syndrome. Reference Book of the Policlinic Doctor, 8, 37-39. In Russ.

4. Drapkina O.M., Yemelyanov A.V. (2013). Fibrosis and atrial fibrillation - mechanisms and treatment. Arterial Hypertension, 19, 6, 487-494. In Russ.

5. Oganov R.G. (2002). Prevention of cardiovascular diseases: possibilities of practical health care. Cardiovascular Therapy and Prevention, 1, 15-16. In Russ.

6. Ahmad T., Fiuzat M., Neely B. et al. (2014). Biomarkers of myocardial stress and fibrosis as predictors of mode of death in patients with chronic heart failure. JACC Heart Fai., 2, 3, 260-268. doi: 10.1016/j. jchf.2013.12.004.

7. Ho J.E., Yin X., Levy D. et al. (2014). Galectin 3 and incident atrial fibrillation in the community. Am. Heart J., 167, 5, 729-734.

8. Belluzzi F., Sernesi L., Preti P. et al. (2009). Prevention of recurrence lone atrial fibrillation by the angiotensin-II converting enzyme inhibitor ramipril in normotensive patients. JACC, 53, 24-29. doi: 10.1016/j. jacc.2008.08.071.

9. Gurses K.M., Yalcin M.U., Kocyigit D. et al. (2015). Effects of persistent atrial fibrillation on serum galectin-3 levels. Am. J. Cardiol., 115, 5, 647-651.

10. Ionin V.A., Listopad O.V., Nifontov S.E. et al. (2014). Galektin 3 in patients with metabolic syndrome and atrial fibrillation. Arterial Hypertension, 2O, 5, 462469.

11. Boss Ch.J., Lip G.Y.H. (2005). Targeting the reninangiotensin-aldosterone system in atrial fibrillation: from pathology to clinical trials. J. Hum. Hypertens., $19,855-859$.

12. Cheruku K.K., Ghani A., Ahmad F. et al. (2004). Efficacy of nonsteroidal anti-inflammatory medications for prevention of atrial fibrillation following coronary artery bypass graft surgery. Prev. Cardiol., 7, 1, 13-18.

13. Sideris A.N., Letsas K. (2006). Inflammation and atrial fibrillation. Hospital Chronicles. Suppl., 128134 .

14. Weber M., Hamm C. (2006). Role of B-type natriuretic peptide (BNP) and NT-proBNP in clinical routine. Heart, 92, 6, 843-849. doi: 10.1136/ hrt.2005.071233.

15. Shlyakhto E.V., Nedogoda S.V., Konradi A.O. et al. (2016). The concept of novel national clinical guidelines on obesity. Russ. J. Cardiol., 21, 4, 7-13. doi. org/10.15829/1560-4071-2016-4-7-13. In Russ.

\section{ABOUT THE AUTHORS}

Yakhontov Davyd Aleksandrovich - Dr. Sci. (Med.), Professor of the Department of Pharmacology, Clinical Pharmacology and Evidentiary Medicine, Novosibirsk State Medical University.

Khidirova Lyudmila Daudovna - Cand. Sci. (Med.), Associate Professor of the Department of Pharmacology, Clinical Pharmacology and Evidentiary Medicine, Novosibirsk State Medical University. 
макологии и доказательной медицины ФГБОУ ВО «Новосибирский государственный медицинский университет» Минздрава России.

Зенин Сергей Анатольевич - д-р мед. наук, заведующий отделением аритмологии Новосибирского областного клинического кардиологического диспансера.

Образец цитирования : Яхонтов Д.А., Хидирова Л.Д., Зенин С.А. Оценка некоторых клиникопатогенетических взаимосвязей у больных фибрилляцией предсердий в сочетании с артериальной гипертонией и экстракардиальной патологией // Journal of Siberian Medical Sciences. 2019. № 2. C. 29-37.
Zenin Sergey Anatolyevich - Dr. Sci. (Med.), Head of the Department of Arrhythmology, Novosibirsk Regional Clinical Cardiologic Dispencary.

Citation example: Yakhontov D.A., Khidirova L.D., Zenin S.A. (2019). Assessment of some clinical pathogenetic interactions in patients with atrial fibrillation in combination with the arterial hypertension and extracardiac pathology. Journal of Siberian Medical Sciences, 2, 29-37. 